\title{
Epoxidation of Neral/Geranial Using a Jacobsen-Katsuki Mn catalyst by Chemical and Electrochemical Methods
}

\author{
Omar Portilla-Zúñiga, ${ }^{1}$ Marco Fidel Mosquera-Ramírez, ${ }^{1}$ Jaime Martín-Franco, ${ }^{2}$ \\ Olga Lucía Hoyos-Saavedra ${ }^{1}$ and Germán Cuervo-Ochoa ${ }^{1 *}$ \\ ${ }^{1}$ Grupo de Investigación en Procesos Electroquímicos \\ ${ }^{2}$ Grupo de Investigación en Química de Productos Naturales, Departamento de Química, Universidad del Cauca, Popayán \\ 190003, Colombia
}

Corresponding author: Tel +573148114790 Fax +5728209800 ext 2306

Edificio de Laboratorios. Sector Tulcán. Carrera 2 No. 3N-100. Popayán, Cauca, Colombia

E-mail address: gcuervo@unicauca.edu.co (G. Cuervo-Ochoa)

Received June 15 ${ }^{\text {th }}, 2015$; Accepted November $24^{\text {th }}, 2015$.

\begin{abstract}
In this study, trans-( \pm )- $N, N^{\prime}$-bis(salicylidene)-1,2-cyclohexanediaminemanganese(III) chloride $([\mathrm{Mn}(t$-salcn) $] \mathrm{Cl})$ was synthesized and used as a catalyst for the epoxidation of citral. The percentage of converted citral in two methods, chemical and electrochemical, was determined and compared; in the former method, the oxidizing agent $\mathrm{NaClO}$ was directly and completely added at the start of the reaction, while in the latter, $\mathrm{ClO}^{-}$was progressively generated in situ. The reaction was monitored by the quantification of citral using gas chromatography coupled to mass spectrometry. The results showed that in both cases, the major products correspond to epoxides from citral isomers, although differences were observed in the value of percentage of epoxides obtained, besides the generation of side reactions affecting the yield of the product of interest.
\end{abstract}

Key words: Epoxidation; Electrochemical synthesis; Citral; Neral; Geranial.

\section{Introduction}

Epoxides are organic compounds of significance in fine organic synthesis; they are used as precursors to obtain molecules of biochemical interest. The 6,7-epoxide of citral is utilized for the synthesis of 1,2-epoxy-carotenoides such as 1,2-epoxy-lycopene and 1,2,1',2'-diepoxy-lycopene [1], which are well-known antioxidants and inflammatory mediators; it is also utilized for the synthesis of complex heterocyclic derivatives, which have permitted mechanistic investigation of reactions involving carbocations [2]. In addition, the 2,3-epoxide of the same compound is an important precursor for the synthesis of different benzofurans of interest, due to the biological activity of its derivatives [3]. Different reactions have been employed for the generation of epoxides [4,5], and studies have been ongoing with the aim of improving the yield and enantioselectivity of reactions [6-8].

Typically, epoxidation is conducted using a catalyst, which modifies the rate of reaction as well as controls the intensity
Resumen. En este estudio se sintetizó el compuesto cloruro de trans-( \pm )- $N, N$ '-bis(salicilideno)-1,2-ciclohexanodiaminomanganeso(III) $([\mathrm{Mn}(t$-salcn $)] \mathrm{Cl})$ y se empleó como catalizador en la reacción de epoxidación de citral. Se determinó el porcentaje de conversión de citral al adicionar directa y completamente hipoclorito de sodio como agente oxidante desde el comienzo de la reacción y se comparó con el porcentaje de reacción de citral con el mismo agente oxidante generado progresivamente in-situ a través de un proceso electroquímico. El seguimiento de la reacción se realizó mediante la cuantificación de citral por cromatografía de gases acoplada a espectrometría de masas. Los resultados mostraron que en ambos casos los productos mayoritarios corresponden a epóxidos de los isómeros de citral, pero se encontraron diferencias en el valor de los porcentajes de epóxidos obtenidos, además de la generación de reacciones secundarias que afectan el rendimiento del producto de interés.

Palabras Clave: Epoxidación; Síntesis electroquímica; Citral; Neral; Geranial

and the selectivity of oxidation. Jacobsen [9] reported one of the most representative studies on the epoxidation of olefins [9], in which the Schiff's base $N, N^{\prime}$-bis(3,5-di-tert-butylsalicylidene)-1,2-cyclohexanediamine and manganese(III) was used as precursor of the complex $N, N^{\prime}$-bis(3,5-di-tert-butylsalicylidene)-1,2-cyclohexanediaminomanganese(III) chloride, known as Jacobsen's catalyst. This catalyst and those of its type contain a $\mathrm{Mn}^{3+}$ metallic center, which is oxidized to $\mathrm{Mn}^{5+}$ at activation. Activation is performed by the addition of an oxidizing agent. For some widely studied epoxidation reactions with the use of Jacobsen-type catalysts [5,10-12], a high conversion percentage, as well as enantiomeric excess, has been reported.

Most of the abovementioned synthetic routes to epoxides involve a direct chemical reaction between the substrate and catalyst, which has been previously activated by an oxidizing agent added from the start into the reaction container. However, the oxidizing agent can compete with the catalyst for the substrate, thereby generating products with a degree of oxidation higher than that required for the epoxides. 
In recent years, biphasic chemical and electrochemical systems have been employed $[13,14]$, affording products of greater purity. Biphasic systems allow for the use of catalysts with low or null solubility in water, given that the activation of the catalyst possibly occurs at the interface between water and the organic solvent. In addition, in biphasic electrochemical systems, it is possible to control the amount of oxidizing agent and the rate at which it is added to the system so as to improve the percentage conversion as well as the selectivity of epoxidation. These systems permit the use of oxidizing agents that are soluble in water and insoluble in organic solvents, where direct contact between the oxidizing agent and the substrate is decreased.

The conventional oxidizing agents used in epoxidation are sodium hypochlorite [12], dimethyldioxirane [15, 16], iodosylbenzene $[17,18]$, and hydrogen peroxide $[19,20]$; nevertheless, hypochlorite $\left(\mathrm{ClO}^{-}\right)$is most commonly used because of its high percentage of active oxygen [21]. Jacobsen [12] and Meunier [22] have independently used $\mathrm{ClO}^{-}$for the epoxidation of cis$\beta$-methyl styrene and epoxidation of cyclohexane, respectively. The reaction between $\mathrm{ClO}^{-}$and the catalyst involves the oxidation of the metallic center from $\mathrm{Mn}(\mathrm{III})$ to $\mathrm{Mn}(\mathrm{V})$ and the consequent reduction from $\mathrm{ClO}^{-}$to $\mathrm{Cl}^{-}$. The olefin substrate forms an epoxide, while the oxidized catalyst returns back to $\mathrm{Mn}$ (III) [23]. For epoxidation by the classical chemical method and using biphasic systems, $\mathrm{ClO}^{-}$is completely added to the aqueous phase at the start of the reaction and remains in contact with the catalyst and substrate at the interface. Hence, reactions typically occur directly between the oxidant and substrate, generating undesired products (especially alcohols and/or aldehydes); these products decrease the yield of epoxide.

For electrochemical epoxidation in biphasic systems, $\mathrm{ClO}^{-}$ is electrochemically generated in the aqueous phase by the oxidation of $\mathrm{Cl}^{-}$on the surface of a platinum electrode. The electrogenerated $\mathrm{ClO}^{-}$migrates to the interface and activates the catalyst dissolved in the organic phase by the oxidation of its metallic center, while $\mathrm{ClO}^{-}$is reduced again to $\mathrm{Cl}^{-}$. Then, the substrate, also dissolved in the organic phase, forms an epoxide with the activated catalyst, while the catalyst returns to its original oxidation state (Fig. 1). Nevertheless, in this case, direct contact between $\mathrm{ClO}^{-}$and the substrate can also occur at the interface and affect the yield and purity of the product, in the same manner as in the chemical process.

The principal difference between the chemical and electrochemical processes lies in the control of the rate of the addition of the oxidizing agent when it is generated electrochemically, and consequently in the lower $\mathrm{ClO}^{-}$concentration at the interface as compared to the scenario observed in the chemical process. Because of this difference in the concentrations of $\mathrm{ClO}^{-}$in the aqueous phase, and hence at the interface, it is imperative to establish the preference of the hypochlorite to react with the catalyst or with the substrate in the chemical and electrochemical reactions.

The electrochemical generation of the oxidizing agent in aqueous media is a methodology that contributes to reduce the use of auxiliary substances and toxic solvents. It also allows the atomic saving due to the fact that the amount of produced

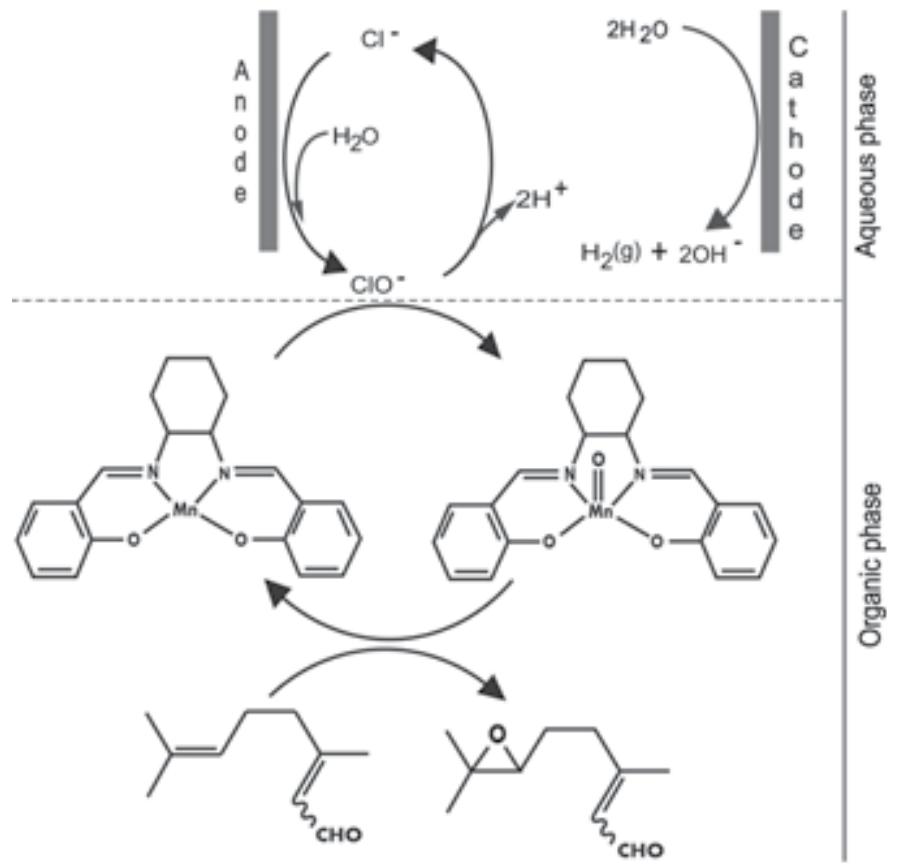

Fig. 1. Representation of electrochemical epoxidation mechanism in a biphasic system.

substance is just that required by chemical reaction. The reduction of number and quantity of residues is an additional benefit. Due to all these aspects, the electrochemical methods are considered an important tool for development of green chemistry $[24,25]$.

To determine the effect of the oxidizing agent on the percentage conversion in both chemical and electrochemical epoxidation, herein, we compared the performance of the epoxidation of citral using the trans-( \pm )- $N, N^{\prime}$-bis(salicylidene)-1,2-cyclohexanediaminemanganese(III) chloride, a $[\mathrm{M}(t$-salcn) $)$ Cl-type catalyst, and the electrochemical generation of the oxidizing agent $\mathrm{ClO}^{-}$utilized for catalyst activation, with the epoxidation of citral using the same catalyst, activated by the direct and complete addition of $\mathrm{ClO}^{-}$from the start of the reaction. In both processes, biphasic systems were used. The aforementioned trans-( \pm )- $N, N^{\prime}$-bis(salicylidene)-1,2-cyclohexanediamine manganese(III) chloride catalyst was synthesized by the electrochemical method via the reaction between $\mathrm{Mn}(\mathrm{III})$ and the trans-( \pm$)-N, N^{\prime}$-bis(salicylidene)-1,2-cyclohexanediamine $\left(\mathrm{H}_{2} t\right.$ salcn) ligand, which was also synthesized in our laboratory.

In this study, the enantioselectivity of catalyst was not determined because the main purpose of the work was to establish the difficulties and advantages when electrochemical method is used to generate the oxidant agent in controlled form, respect to addition of the same oxidant agent like salt at the start of the reaction.

In this study, the substrate citral $\left(\mathrm{C}_{10} \mathrm{H}_{16} \mathrm{O}\right)$ or 3,7-dimethyl-2,6-octadienal is a mixture of two monoterpene aldehydes: geranial and neral. Geranial (2-(E)-3,7-dimethyl-2,6-octadienal) is the trans isomer, while neral (2-(Z)-3,7-dimethyl-2,6-octadienal) is the cis isomer [26, 27]. Citral is a natural 
compound with significant potential in the pharmaceutical and chemical industries given its broad applications ranging from the generation of citric flavors and aromas to the synthesis of organic macromolecules [28-31]. The essential oil of Cymbopogon citratus is one of the main natural sources of citral, which is known as lemongrass or "limonaria," in South America; it is an aromatic plant with broad global distribution, belonging to the family of Gramineae, with traditional therapeutic uses [32, 33].

\section{Results and discussion}

\section{Synthesis and characterization of the $\mathrm{H}_{2} t$-salen ligand}

The $\mathrm{H}_{2} t$-salcn Schiff's base was obtained in $95 \%$ yield; it is not a conductor and is not soluble in water, but it is slightly soluble in non-polar chlorinated solvents such as dichloromethane and aromatic solvents such as toluene. Spectroscopic characterization via UV-Vis, FTIR, ${ }^{1} \mathrm{HNMR}$, and ${ }^{13} \mathrm{C}$ NMR confirmed that the structure of the compound obtained corresponds to the expected ligand (structure 1).

\section{Electrosynthesis and characterization of the [Mn(t-salcn)] Cl complex}

The yield of the complex synthesized at room temperature was $88.0 \%$. The compound obtained was a 1:1-type electrolyte, indicating that $\mathrm{Cl}^{-}$is outside the coordination sphere of manganese; moreover, it is soluble in chloroform, DMSO, and DMF, albeit with low solubility in water. Elemental analysis confirmed the general formula to be $\mathrm{C}_{20} \mathrm{H}_{20} \mathrm{~N}_{2} \mathrm{O}_{2} \mathrm{MnCl}$ (structure 2 ) without coordinated water. The percentage of chloride was obtained by potentiometric evaluation with $\mathrm{AgNO}_{3}$, the percentage of Mn was obtained by atomic absorption spectrophotometry, and the percentage of oxygen was determined by difference.

The coordination of the ligand to manganese(III) was confirmed by FTIR spectroscopy, as evidenced by the variation in the absorption frequency of the $\mathrm{C}=\mathrm{N}$ group of the ligand and

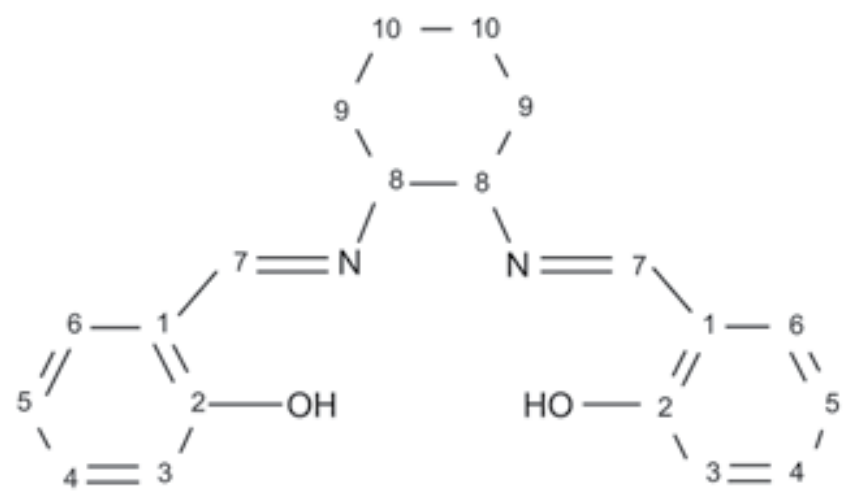

Structure 1. Trans-( \pm -) $N, N^{\prime}$-bis(salicylidene)-1,2-cyclohexanediamine $\left(\mathrm{H}_{2} t\right.$-salcn) ligand.

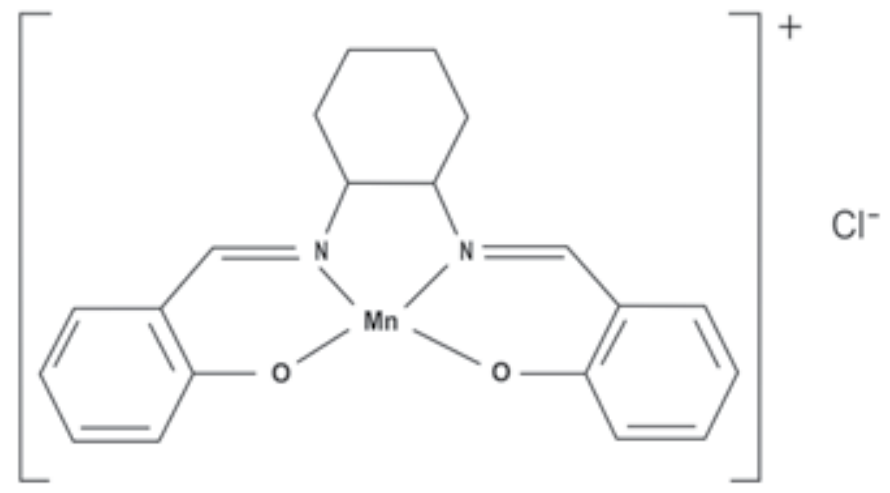

Structure 2. Trans- $( \pm)-N, N^{\prime}$-bis(salicylidene)-1,2-cyclohexanediaminemanganese (III) chloride $([\mathrm{Mn}(t$-salcn $)] \mathrm{Cl})$.

the off-plane vibration of the $\mathrm{C}-\mathrm{O}$ bond. In addition, an anodic peak $(-95 \mathrm{mV})$ and a cathodic peak $(-265 \mathrm{mV})$ were observed in the cyclic voltammogram of the complex dissolved in $\mathrm{MeCN}$ with $0.1 \mathrm{M}$ tetrabutylammonium perchlorate using a mercury drop electrode (Fig. 2), both characteristic of the complex, which were not observed for the ligand or metal. The quasi-reversible electrochemical signals are attributed to equilibrium between $\left[\mathrm{Mn}^{\mathrm{II}} \text {-salcn }\right]^{0}$ and $\left[\mathrm{Mn}^{\mathrm{III}} \text {-salcn }\right]^{+}$, in analog form to showed by Horwitz and co-workers [34].

\section{Chemical epoxidation}

The chemical process was examined by gas chromatography; with the increase in the concentration of the catalyst in the reaction system, the disappearance of citral progressively increased until it reached a value close to $77 \%$ with $5 \mathrm{~mol} \%$ catalyst (Fig. 3). Moreover, with the increase in the catalyst concentration to $15 \mathrm{~mol} \%$, the rate of disappearance of the starting material slightly increased to $83 \%$. Considering these results, a catalyst concentration of $5 \mathrm{~mol} \%$ was employed in subsequent experiments.

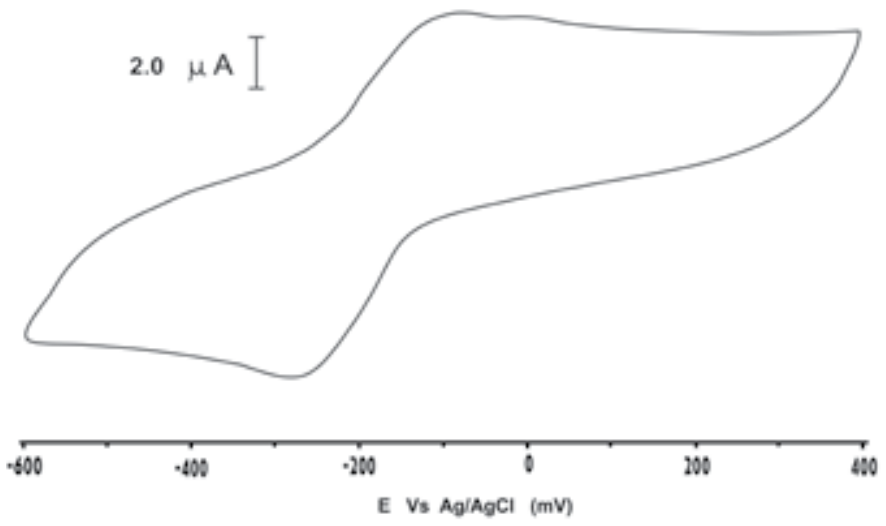

Fig. 2. Cyclic voltammetry for $[\mathrm{Mn}(t$-salcn $)] \mathrm{Cl}$ complex dissolved in $\mathrm{MeCN}$ with $0.1 \mathrm{M}$ tetrabutylammonium perchlorate at mercury drop electrode. Scan rate $100 \mathrm{mV} / \mathrm{s}$. 


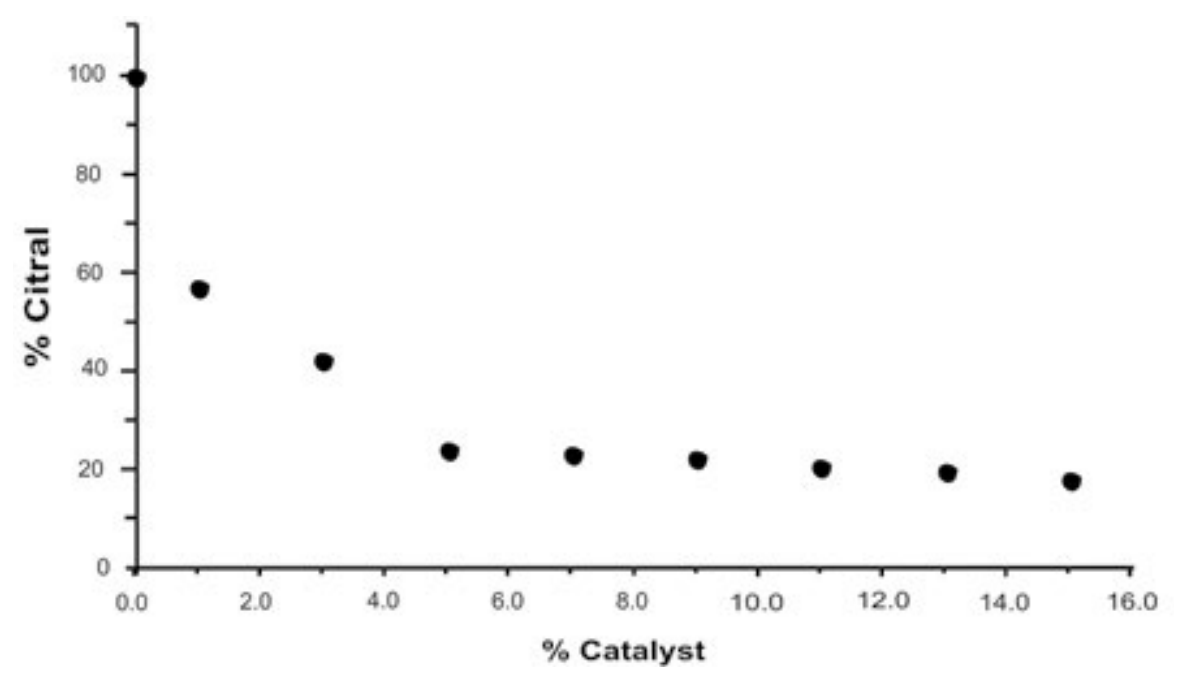

Fig. 3. Variation of the reaction percentage of citral as a function of catalyst concentration. Reaction time $8 \mathrm{~h}$.

The percentage of the disappearance of citral reported was calculated after the subtraction of the loss of this substrate by volatilization at each stage during the progress of the experiment, which amounted to $14 \%$. Moreover, after $4 \mathrm{~h}$ of the addition of the oxidizing agent, citral reaction percentage values reached $36 \%$. Furthermore, at $8 \mathrm{~h}$, the substrate conversion reached a maximum of $68 \%$, and between 8 and $16 \mathrm{~h}$, this percentage only increased marginally by $1 \%$.

Fig. 4 shows the effect of the oxidizing agent with time; results obtained indicated that with the decrease in the concentration of $\mathrm{ClO}^{-}$in the system, only one tenth of its initial value was reached at $8 \mathrm{~h}$ (Fig. 4). Taking into account that at 8 $\mathrm{h}$, the conversion of citral reached only $68 \%$ and that the initial $\mathrm{ClO}^{-}$concentration was stoichiometrically equivalent to that of citral, a less-pronounced decrease for the $\mathrm{ClO}^{-}$content in the solution would be expected. Nevertheless, $\mathrm{ClO}^{-}$was notably consumed more rapidly than the substrate, which implies that the oxidant is consumed. This result suggest that $\mathrm{ClO}$ - active the catalyst, but also directly reacts with citral or participates in secondary reactions possibly involving catalyst degradation.

\section{Electrochemical epoxidation}

\section{Electrochemical generation of hypochlorite}

The electrochemical generation of $\mathrm{ClO}^{-}$from sodium chloride was carry out applying a current density of $20 \mathrm{~mA} / \mathrm{cm}^{2}$, the initial and final potential values were 2.2 and $2.4 \mathrm{~V}$ respectively during eight hours. The process was monitored in the same manner as for the chemical method. Initially, $\mathrm{ClO}^{-}$generated was evaluated in a blank cell, that is, without the presence of the catalyst and without citral. Thereafter, $\mathrm{ClO}^{-}$from the

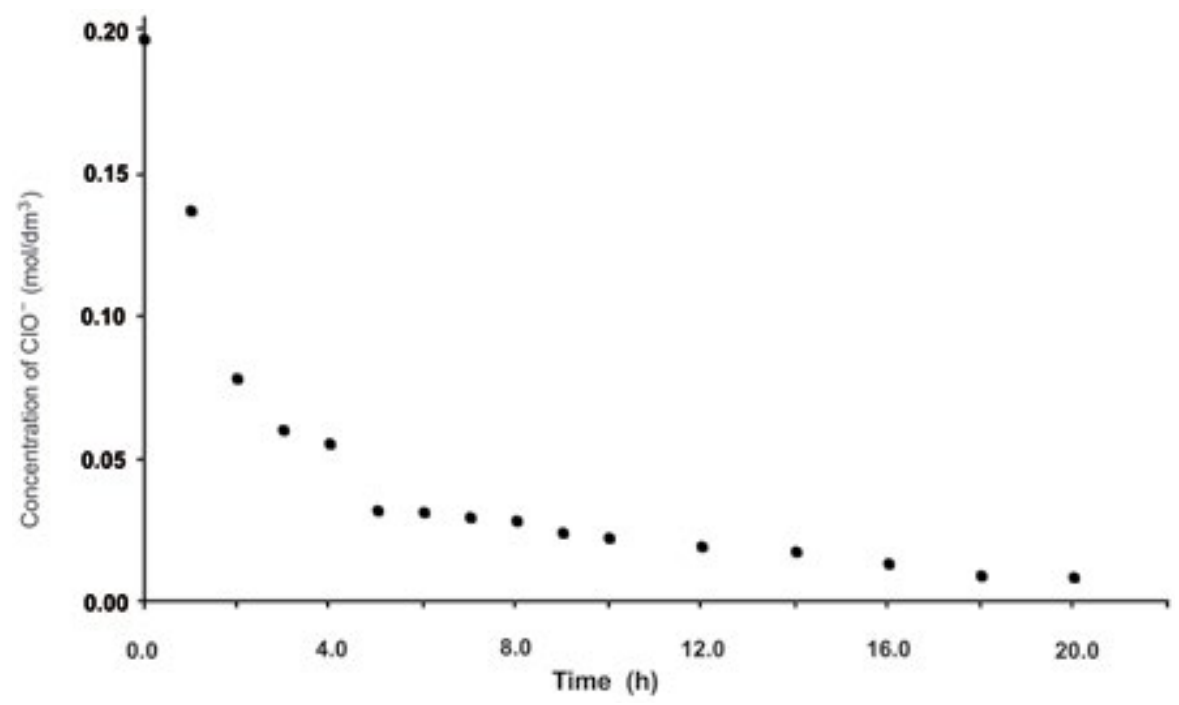

Fig. 4. Variation of the $\mathrm{ClO}^{-}$concentration as a function of the epoxidation time for citral by the chemical method. 


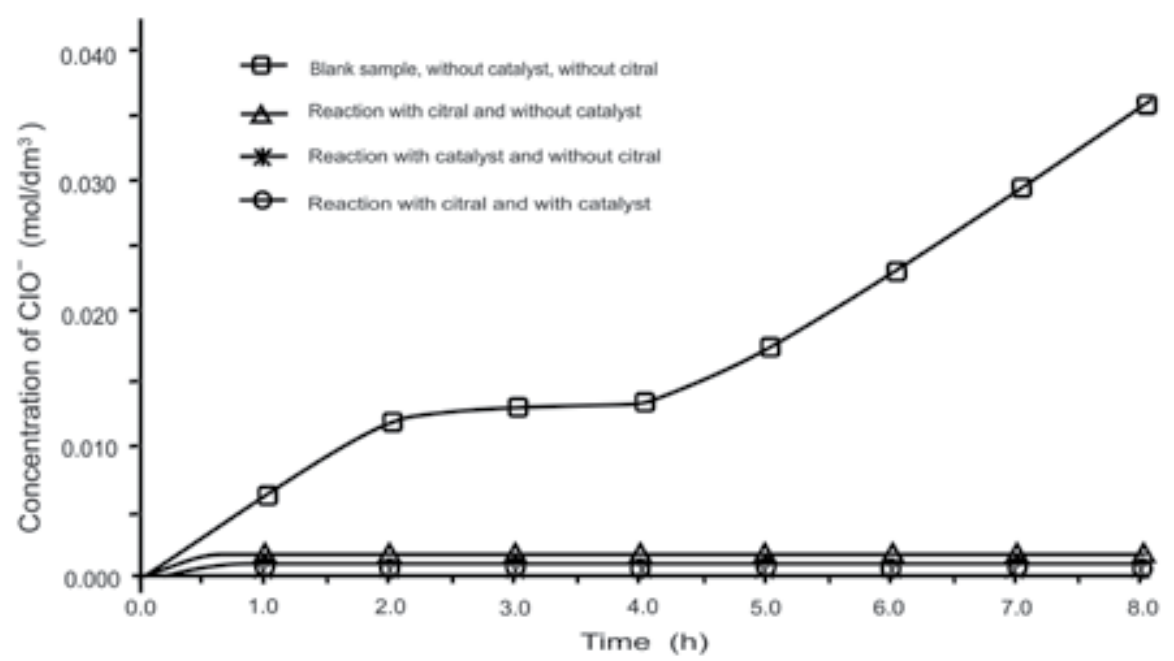

Fig. 5. Determination of hypochlorite generated during electrochemical epoxidation at $20 \mathrm{~mA} / \mathrm{cm}^{2}$ in the presence and absence of each component.

solution containing citral, and not the catalyst, was titrated. Third, $\mathrm{ClO}^{-}$from the solution containing the catalyst but not citral was evaluated, and finally, $\mathrm{ClO}^{-}$was titrated in the solution containing citral and catalyst at concentrations mentioned in the experimental section. The results obtained (Fig. 5) confirm the generation of $\mathrm{ClO}^{-}$in the electrochemical cell, also indicating its increased concentration in the blank cell, as a function of time. For the cell with the catalyst, the electrogenerated $\mathrm{ClO}^{-}$was completely and immediately consumed, indicating that the oxidizing agent reacts with the catalyst as expected; however, because the activated catalyst was not being used up (absence of substrate), the rate of disappearance of $\mathrm{ClO}^{-}$ would be expected to not be as high as that observed during titration. At this stage, it was not possible to verify whether the reaction between both species was as expected, that is, the oxidation of the metallic center of the catalyst and generation of chloride from hypochlorite. $\mathrm{ClO}^{-}$also rapidly disappeared in the cell containing citral but not containing the catalyst, indicating that the substrate is directly oxidized by the oxidizing agent without catalyst mediation. Finally, upon assessing $\mathrm{ClO}^{-}$generated in the cell containing citral and catalyst in the organic phase, the oxidizing agent immediately disappeared, confirming that hypochlorite rapidly reacts with both catalyst and substrate. Fig. 5 shows the evaluation curves for each of the cells previously described.

From the results obtained by the electrochemical method, a greater decrease of the substrate concentration at a reaction time of $4 \mathrm{~h}$ was observed as compared to that observed for the chemical method, with a citral reaction percentage of $42 \%$. Moreover, at time greater than $4 \mathrm{~h}$, the increase observed was less than $4 \%$, which was attributed to the passivation observed on both electrodes as well as catalyst inactivation.

Electrode passivation observed at a reaction time greater than $4 \mathrm{~h}$ was attributed to the presence of an oily film, which was not observed in systems without the catalyst; thus, the oily film is attributed to the deposition of the catalyst or degradation products of the catalyst generated by reaction with $\mathrm{ClO}^{-}$. From the aforementioned result, it is inferred that the catalyst is transferred from the organic phase to the aqueous phase. The presence of the catalyst in the aqueous phase was confirmed by UV-Vis spectroscopy: three well-defined absorption signals were observed, which disappear on the addition of $\mathrm{ClO}^{-}$. The partial loss of the catalyst means that there is less chance of reaction with citral as well as the passivation of the electrodes, resulting in the restriction or obstruction of the oxidation from $\mathrm{Cl}^{-}$to $\mathrm{ClO}^{-}$.

The oily film deposited on the electrodes is possibly generated by the irreversible formation of $\mu$-oxo-manganese(IV) inactive dimeric films on the anode of the cell, associated with the oxidation of the metallic nucleus of the catalyst, and likewise, to that generated in the $\mathrm{C}=\mathrm{N}$ double bond of the organic ligand used in the complex, attributed to the use of oxidizing agents such as $\mathrm{ClO}^{-}$[16], which could be responsible for the rapid disappearance of $\mathrm{ClO}^{-}$in the cells containing only the catalyst.

\section{Gas Chromatography-Mass Spectrometry Analysis}

After $4 \mathrm{~h}$ of the reaction, the products generated from electrochemical epoxidation in the presence of the catalyst were extracted with hexane. Fig. 6 shows the chromatogram obtained from the analysis of the extract by gas chromatography coupled to mass spectrometry. The most intense signals were observed at 4.0 and $5.5 \mathrm{~min}$, corresponding to neral and geranial isomers, respectively. To establish the citral reaction percentage, the sum of the areas of both isomers after the reaction time was determined and compared to the same sum of areas at zero reaction time, subtracting the loss of material during the different steps of the process. The following signal intensity is the internal pattern signal (eugenol), which appeared at $12.10 \mathrm{~min}$. Signals were observed at 8.66 and $9.76 \mathrm{~min}$, corresponding to the major products in the reaction; these signals appeared with an area significantly smaller than expected, given that material loss occurred during the extraction of the reaction products in case of citral isomers. For citral, such loss increased to $14 \%$, while for 


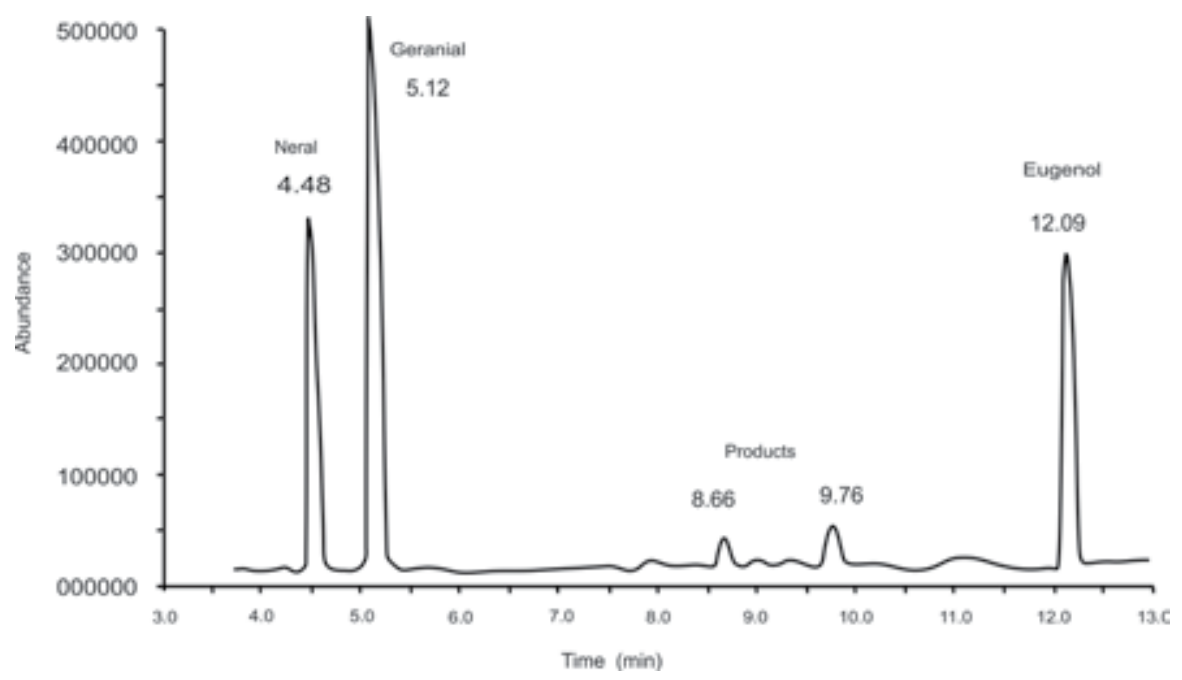

Fig. 6. Chromatogram obtained from the extract of the reaction products of the epoxidation of citral by the electrochemical process at a reaction time of $4 \mathrm{~h}$.

the products generated, the percentage of loss could not be established. Fig. 7 shows the fragmentation patterns of the major products obtained by ionization through electronic impact.

As shown in the mass spectra in fig. 7a, the most intense signals were observed at $\mathrm{m} / \mathrm{z} 82$, corresponding to the base peak, and $\mathrm{m} / \mathrm{z} 95$. From the mass spectra in fig. $7 \mathrm{~b}$, the base peak was observed at $\mathrm{m} / \mathrm{z} 81$, and another signal was obtained at $\mathrm{m} / \mathrm{z} 97$. In both cases, the $\mathrm{m} / \mathrm{z}$ signals, which were lower than the base peak, coincide with the signals observed in the mass spectra of citral isomers. By analyzing the fragments of each signal, a
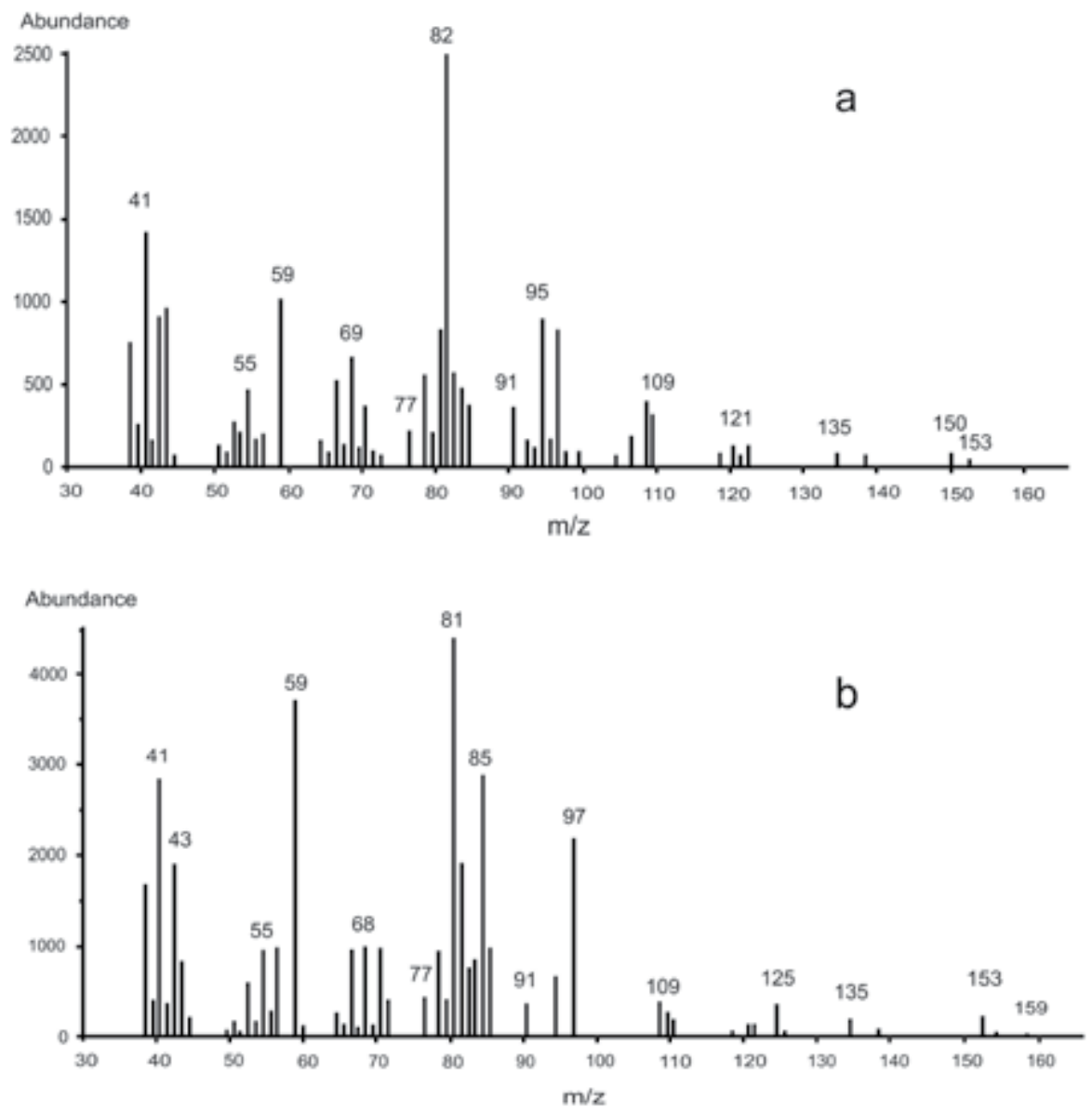

Fig. 7. Mass spectra obtained via electronic impact, showing signals at retention times of a) $8.66 \mathrm{~min}$ b) $9.76 \mathrm{~min}$, from Fig. 5 . 
partition mechanism (Figures 8 and 9) was observed, where the starting species neral epoxide was generated, whose fractioning pattern coincided with the mass spectra in fig. $7 \mathrm{a}$, and geranial epoxide whose fractioning pattern coincided with the mass spectra in fig. $7 \mathrm{~b}$.

The characteristic fragments for each citral epoxide had the formula $\mathrm{C}_{10} \mathrm{H}_{16} \mathrm{O}_{2}$, consistent with the signal at $\mathrm{m} / \mathrm{z} 168$; this signal was not visible in the spectrum; however, despite having equal molecular mass, the neral and geranial epoxide isomers exhibited different fragmentation processes. The principal difference lies in the $\mathrm{m} / \mathrm{z}$ ratio of the base peak given that fragmentation is directly related to the spatial orientation of the aldehyde group. For neral epoxide (cis-citral), the carbonyl group was the closest to the carbon chain; hence, fragmentation favors the formation of a stable five-membered heterocycle, corresponding to the base peak for the said epoxide (Fig. 8). Moreover, for geranial epoxide (trans-citral), the carbonyl group was away from the chain, which impedes the formation of the heterocycle described for neral, and consequently, fragmentation ends, generating a different base peak (Fig. 9).

The formation of the $\mathrm{m} / \mathrm{z} 95$ fragments of neral epoxide and $\mathrm{m} / \mathrm{z} 97$ fragments of geranial epoxide was explained in the same manner as the fragment base because of the proximity of the carbon chain to the carbonyl group of the aldehyde. Neral epoxide favored the formation of a six-atom heterocycle, while in geranial epoxide, the proximity of the carbonyl as well as the formation of the heterocycle were impeded; hence, a stable linear fragment is formed. Figures 8 and 9 show the mechanisms proposed for the fragmentation of both citral epoxides based on the mass spectra from figures $7 \mathrm{a}$ and $\mathrm{b}$.

By analyzing the fragments, the epoxidation of citral was confirmed to occur at $\mathrm{C}_{6}-\mathrm{C}_{7}$ positions. The fragment at $\mathrm{m} / \mathrm{z} 85$ was explained as a three-membered heterocyclic system: two carbon atoms and one oxygen atom; nevertheless, this last fragment was observed with high intensity in geranial epoxide, caused by the difference in the fragmentation mechanisms justified by the position of the aldehyde group with respect to the remainder of the carbon chain. From the aforementioned result, epoxidation clearly occurs primarily at the double bond between carbons $\mathrm{C}_{6}$ and $\mathrm{C}_{7}$ of citral given that this bond has a higher electronic density, caused by the presence of the bonded electron-donating groups. The epoxidation described is similar in its selectivity to the process performed with peroxo species; hence, it is presumed that the active species of the catalyst is a marked electrophile.
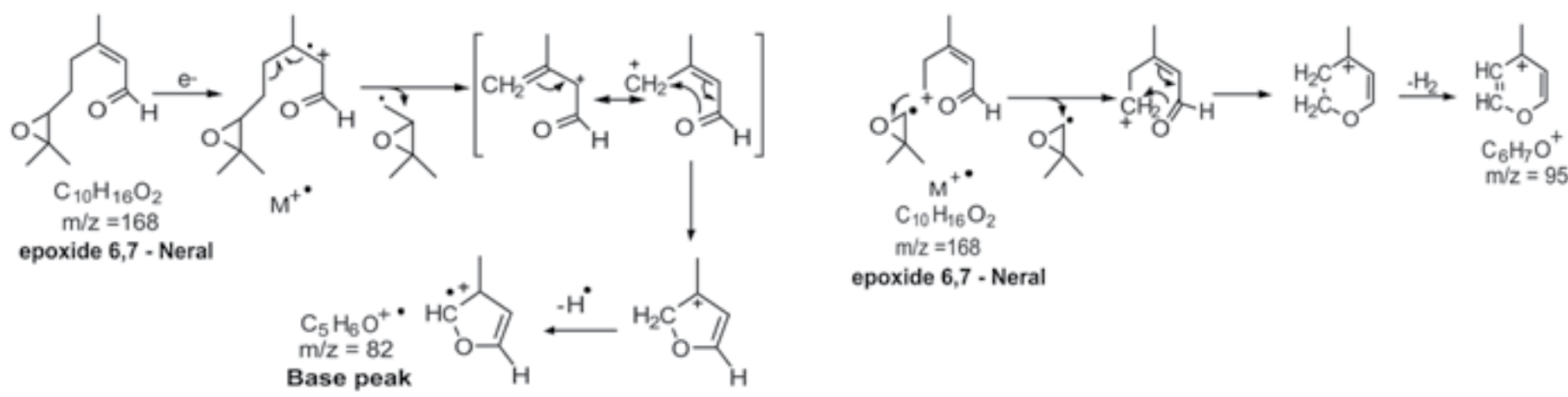

Fig. 8. Fragmentation pattern of 6, 7-neral epoxide.
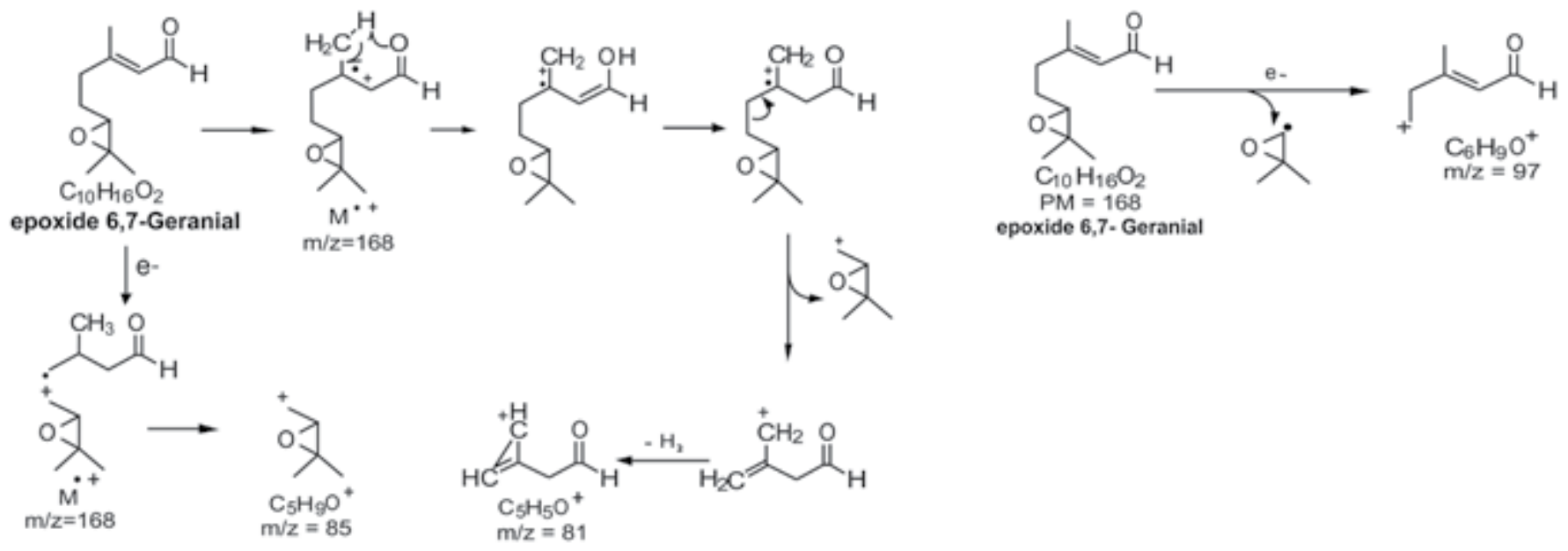

Fig. 9. Fragmentation pattern of 6, 7-geranial epoxide. 


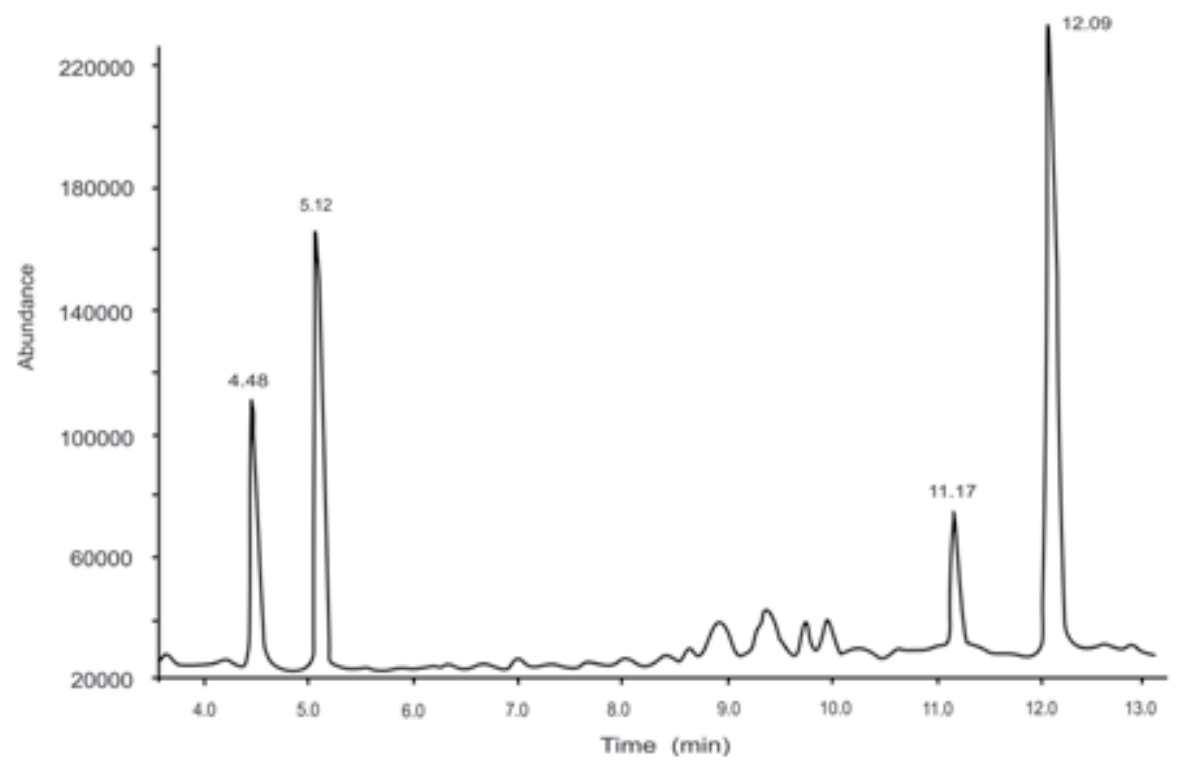

Fig. 10. Chromatogram obtained from products extracted from blank cell (system without catalyst) for chemical and electrochemical methods after $8 \mathrm{~h}$ of reaction.

From the gas chromatography analysis of the extract of the products from citral epoxide by the chemical method, peaks were also observed at retention times of 8.66 and 9.76; however, in this case, three additional signals with intensities and areas similar to those of epoxides were also observed, which were not identified. This is proof of the higher selectivity of the electrochemical process and suggests that $\mathrm{ClO}^{-}$exhibits a greater affinity for the catalyst when $\mathrm{ClO}^{-}$is added in a slow and controlled manner.

In case of the reaction blanks (systems without the presence of catalyst) in both chemical and electrochemical methods, the chromatograms obtained (Fig. 10) provided evidence for the formation of products different from the epoxides, which appeared at retention times coinciding with unidentified products of the chemical reaction; hence, it is inferred that these products correspond to the oxidation products of citral by the direct reaction with $\mathrm{ClO}^{-}$. In addition, the major product was observed at a retention time of $11.17 \mathrm{~min}$, whose fractionation pattern suggests the non-selective oxidation of double bonds of citral over simple epoxidation. This suggests that in a biphasic system, $\mathrm{ClO}^{-}$can simultaneously participate in three reactions: first, the metallic center of the catalyst undergoes oxidation to achieve the activation of the last process, which is the complete process that culminates in the epoxidation of the substrate; second, the ligand catalyst undergoes oxidation, leading to the degradation of the complex, and finally, the direct oxidation of citral to alcohols or aldehydes.

\section{Experimental section}

\section{Materials}

HPLC-grade acetonitrile (MeCN), petroleum ether, GC-grade ethyl acetate (Fisher Scientific), citral (95\%), GC-MS-grade salicylaldehyde (Aldrich Chemistry), eugenol (99\%), metallic manganese (Fluka Chemika), GC-grade dichloromethane (J.T. Baker), perchloric acid (72\%), hydrated potassium dibasic phosphate (99\%), monohydrated potassium monobasic phosphate $(99 \%)$, GC-grade hexane, platinum sheets $\left(1 \mathrm{~cm}^{2}\right)$, platinum wire $(0.3 \mathrm{~mm})(99.99 \%)$, trans- $( \pm)$-1,2-cyclohexanediamine (99.5\%), dimethylformamide (DMF), chloroform (Merck), tetrabutylammonium bromide (Aldrich), and dimethyl sulfoxide (DMSO) (Pancreac) were all used as received.

\section{Synthesis of the $\mathrm{H}_{2}$-salen ligand}

First, salicylaldehyde was added to an aqueous solution of trans- $( \pm)-1,2$-cyclohexanediamine in a stoichiometric ratio of 2:1 and subjected to strong agitation for $45 \mathrm{~min}$. The precipitate was filtered under vacuum, washed in water, and dried for $12 \mathrm{~h}$ at $70{ }^{\circ} \mathrm{C}$.

trans- $( \pm)-N, N^{\prime}$-bis(salicylidene)-1,2-cyclohexanediamine ( $\mathrm{H}_{2} t$-salcn) (1). Yellow powder mp: $117-119{ }^{\circ} \mathrm{C}$, UV-Vis $\left(\mathrm{CHCl}_{3}, \mathrm{~nm}\right) 320\left(\pi-\pi^{*}\right) ; 256,\left(\mathrm{n}-\pi^{*}\right)$. Selected FTIR bands $\left.\left(\mathrm{KBr}, \mathrm{cm}^{-1}\right): 3500, v-\mathrm{OH} ; 2930, v_{(\mathrm{cy})} \mathrm{C}-\mathrm{H} ; 2855, v_{(\mathrm{cy})}\right)^{-\mathrm{CH}_{2}-}$; 1627, vC $=\mathrm{N} ; 1499, v \mathrm{C}=\mathrm{C} ; 1279, v \mathrm{C}-\mathrm{O} ; 762, v_{(\operatorname{ar})}=\mathrm{C}-\mathrm{H} ;{ }^{1} \mathrm{H}$ NMR (500 MHz, $\left.\mathrm{CDCl}_{3}\right): \delta 1.49-1.53(2 \mathrm{H}, \mathrm{mc}$, cyclohexane, $\left.\mathrm{C}_{10} \mathrm{H}\right), 1.75-1.78\left(2 \mathrm{H}, \mathrm{mc}\right.$, cyclohexane, $\left.\mathrm{C}_{10} \mathrm{H}\right), 1.90-1.91(2 \mathrm{H}$, mc, cyclohexane, $\left.\mathrm{C}_{9} \mathrm{H}\right), 1.96-2.05\left(2 \mathrm{H}, \mathrm{mc}\right.$, cyclohexane, $\left.\mathrm{C}_{9} \mathrm{H}\right)$, 3.36-3.34 (2H, m, cyclohexane, $\left.\mathrm{N}-\mathrm{C}_{8} \mathrm{H}\right), 6.81(2 \mathrm{H}$, dt, aromatic, $\left.\mathrm{C}_{5} \mathrm{H}\right), 6.93\left(2 \mathrm{H}\right.$, dd, aromatic, $\left.\mathrm{C}_{3} \mathrm{H}\right), 7.25(2 \mathrm{H}$, dd, aromatic, $\left.\mathrm{C}_{6} \mathrm{H}\right), 7.30\left(2 \mathrm{H}\right.$, ddd, aromatic, $\left.\mathrm{C}_{4} \mathrm{H}\right), 8.29\left(2 \mathrm{H}, \mathrm{s},-\mathrm{N}=\mathrm{C}_{7}(\mathrm{H})-\right)$, 13.35 (1H, s, -OH-). ${ }^{13} \mathrm{C}$ NMR $\left(126 \mathrm{MHz}, \mathrm{CDCl}_{3}\right): \delta 164.72$, $160.98,132.16,131.49,118.68,118.60,116.78,72.69,33.11$, 24.19; EI MS m/z: $322\left(\mathrm{M}^{+}\right) 201\left(\mathrm{C}_{13} \mathrm{H}_{11} \mathrm{NO}^{+}\right) 122\left(\mathrm{C}_{7} \mathrm{H}_{7} \mathrm{NO}^{+}\right)$ $77\left(\mathrm{C}_{7} \mathrm{H}_{7}^{+}\right)$. Elemental analysis $(\%)$ : calculated: $\mathrm{C}, 74.51 ; \mathrm{H}$, 6.88; N, 8.69; Found: C, 74.54; H, 6.87; N, 8.58. 


\section{Electrosynthesis of the $[\mathrm{Mn}(t$-salen $)] \mathrm{Cl}$ complex}

The reactions occurred at room temperature in an open system with a continuous current of $20 \mathrm{~mA}$ applied for $2 \mathrm{~h}$ in a cell comprising manganese and a platinum wire as the sacrificial anode and cathode, respectively, connected to a GW-Instek power source. The working solution was obtained by using the $\mathrm{H}_{2} t$-salcn ligand $(3.3 \mathrm{mg} / \mathrm{mL})$ and lithium chloride $(3.3 \mathrm{mg} /$ $\mathrm{mL}$ ) dissolved in acetonitrile with tetrabutylammonium perchlorate $(0.1 \mathrm{M})$ as the supporting electrolyte. The solid formed was recovered by filtration and dried at $70{ }^{\circ} \mathrm{C}$ for $12 \mathrm{~h}$.

trans- $N, N^{\prime}$-bis(salicylidene)-1,2-cyclohexanediaminomanganese(III) chloride (2): Brown powder: $\mathrm{mp}>300^{\circ} \mathrm{C}$; UVVis $\left(\mathrm{CHCl}_{3}, \mathrm{~nm}\right) 404(\mathrm{~d}-\mathrm{d}), 317\left(\pi-\pi^{*}\right), 254\left(\mathrm{n}-\pi^{*}\right), 213$ $\left(\mathrm{n}-\pi^{*}\right)$. Selected FTIR bands $\left(\mathrm{KBr}, \mathrm{cm}^{-1}\right): 3500, \mathrm{vH}_{2} \mathrm{O} ; 1623$, $v \mathrm{C}=\mathrm{N} ; 1314, v \mathrm{C}-\mathrm{O} ; 753, v_{(\mathrm{ar})}=\mathrm{C}-\mathrm{H} ; 515-624, v \mathrm{Mn}-\mathrm{O} ; 425$, $v \mathrm{Mn}-\mathrm{N}$. Elemental analysis (\%): calculated: C, 58.48; H, 4.91; N, 6.82, O, 7.79; Mn, 13.37; Cl, 8.63; Found: C, 57.77; H, 4.98; $\mathrm{N}, 6.24, \mathrm{O}, 8.78 ; \mathrm{Mn}, 13.28 ; \mathrm{Cl}, 8.87 ; \mathrm{E}_{1 / 2} \mathrm{~V}(\mathrm{SSCE})=-0.187$.

\section{Chemical epoxidation}

Chemical epoxidation was conducted using a biphasic system consisting of a $15.0 \mathrm{~mL}$ aqueous solution of $0.20 \mathrm{M}$ sodium hypochlorite and $0.05 \mathrm{M}$ phosphate buffer solution (PBS) at $\mathrm{pH}$ 11 , which were in in contact with a $0.20 \mathrm{M}$ citral solution and different amounts of the $[\mathrm{Mn}(t$-salcn $)] \mathrm{Cl}$ catalyst $(1-15 \mathrm{~mol} \%)$; both the citral solution and catalyst were dissolved in $10.0 \mathrm{~mL}$ dichloromethane.

\section{Electrochemical epoxidation}

A GW-Instek power source (0-250 V) was used with two platinum electrodes $1.0 \mathrm{~cm}^{2}$ each and with the application of a current density of $20.0 \mathrm{~mA} / \mathrm{cm}^{2}$ at different times $(4,8$, and $16 \mathrm{~h})$ to $15.0 \mathrm{~mL}$ of the aqueous phase composed of $1.0 \mathrm{M}$ sodium chloride in $0.05 \mathrm{M}$ PBS at pH 11.0. Fine measurement of current was done by a calibrated voltammeter (Technomaster inc.) and variation of $\pm 1.0 \mathrm{~mA}$ was get it mean an electronic circuit fabricated in our laboratory. Ten milliliters of the organic phase with identical composition as that used in chemical epoxidation was utilized. The system was subjected to moderate magnetic agitation throughout the process.

At the end of the reaction time, $10.0 \mathrm{~mL}$ of hexane was added, and the phases were separated by decantation. The aqueous phase was washed with hexane (two times with $10.0 \mathrm{~mL}$ each). The organic phase obtained was allowed to decant for 10 min and centrifuged for $15 \mathrm{~min}$, which resulted in the separation of the catalyst insoluble in hexane. Finally, the volume of the supernatant was adjusted to $50.0 \mathrm{~mL}$ with hexane and was analyzed by GC-MS.

In both reaction systems (chemical and electrochemical), $100 \mu \mathrm{L}$ aliquots were taken from the aqueous phase at $1 \mathrm{~h}$ intervals, $0.10 \mathrm{~g}$ of potassium iodide and $1.0 \mathrm{~mL}$ of glacial acetic acid were added to $10.0 \mathrm{~mL}$ of water, and the aliquot solution was back-titrated with sodium thiosulfate using starch as the indicator [35]. This back titration was used to determine the $\mathrm{ClO}^{-}$concentration.

The products obtained from both chemical and electrochemical epoxidation were separated by column chromatography with silica (LC-Si Supelco ${ }^{\circledR}$ ) with a diameter of $40 \mu \mathrm{m}$ as the stationary phase and a 1:1 mixture of ethyl acetate-petroleum ether as the mobile phase, followed by GC-MS analysis. To monitor the reaction, the internal pattern method was used by the addition of $50 \mu \mathrm{L}$ of eugenol to the crude reaction.

\section{Conclusions}

Hypochlorite exhibited a very strong oxidative capacity for the $[\mathrm{Mn}(t-\mathrm{salcn})] \mathrm{Cl}$ complex, given that besides acting on the metallic center of the complex, it reacts with the ligand, resulting in the degradation of the catalyst as well as the deposition of species on the electrodes and passivation of the electrodes in the cell. Both aspects, catalyst loss and electrode passivation, decreased the yield of citral epoxide obtained from the electrochemical method as compared to that obtained from the chemical epoxidation after $4 \mathrm{~h}$ of reaction. Despite the aforementioned result, it may be inferred that a low concentration of $\mathrm{ClO}^{-}$at the interface favors its reaction with the catalyst and not with the substrate, which is confirmed by the lower number of secondary products obtained by the electrochemical reaction as compared to those obtained by the chemical process.

The trans-( \pm )- $N, N^{\prime}$-bis(salicylidene)-1,2-cyclohexanediaminemanganese(III) chloride complex exhibited catalytic activity directing the epoxidation of citral. However, it can migrate from the organic phase to the aqueous phase in the biphasic system. The presence of the catalyst in the aqueous phase made it more susceptible to degradation by reaction with the oxidizing agent.

The electrogeneration of the oxidizing agent in the reaction medium of a biphasic system is a viable route and a good alternative for studying and controlling chemical reactions. However, for the epoxidation of terpene, it is necessary to control the migration of the oxidized species from the catalyst toward the aqueous phase to avoid its degradation and obtain high efficiency with respect to the performance and purity of products.

Neral and geranial epoxides were confirmed as principal reaction products between citral and the $[\mathrm{Mn}(t-\mathrm{salcn})] \mathrm{Cl}$ catalyst, activated by electrochemically generated $\mathrm{ClO}^{-}$. The products were confirmed by gas chromatography-mass spectrometry. In addition, epoxidation occurred in both isomers at the double bond located between carbons at 6 and 7 positions of citral, suggesting that that double bond exhibits nucleophilicity higher than that of the double bond located between carbons 2 and 3 .

The following conditions were established for the chemical epoxidation of citral: catalyst concentration of $5 \mathrm{~mol} \%$ and reaction time of $8 \mathrm{~h}$; under these conditions, the percentage of citral conversion was greater than $60 \%$. However, by the electrochemical method, a higher reaction percentage of $42 \%$ for citral was obtained in $4 \mathrm{~h}$ than with the chemical method (36\%). 


\section{Acknowledgments}

The authors thank Colciencias for providing support to G. Cuervo-Ochoa for the completion of his doctoral studies and for support through the Jóvenes Investigadores Program (2012), by which that entity collaborated with chemist Omar Miguel Portilla for this study, as well as Vicerrectoría de Investigaciones at Universidad del Cauca for financial support for the development of ID-3602 project, under which this study was developed.

\section{References}

1. H. Pfander, M. Kamber and Y. Battegay-Nussbaumefi, Helv. Chim. Acta. 1980, 63, 1367-1376.

2. O:I. Yarovaya, O:V: Salomatina, D:V. Korchagina, M.P. Polovinka and V.A: Barkhash., Russ. J. Org. Chem. 2002, 38, 1594-1605.

3. Y. Zou, M. Lobera, and B.B. Snider, J. Org. Chem. 2005, 70, 1761-1770.

4. T. Katsuki , K.B. Sharpless, J. Am. Chem. Soc. 1980, 18, 5974 5976.

5. P.G. Cozzi, Chem. Soc. Rev. 2004, 33, 410-421

6. B. Yang and T.A. Manz, RSC Adv. 2015, 5, 12311-12322

7. M. Cokoja, I.E. Markovits, M.H. Anthofer, S. Poplata, A. Pöthig, D.S. Morris, P.A. Tasker, W.A. Herrmann, F.E. Kühn and J.B.Love, Chem. Commun. 2015, Advance Article

8. B. Gao, J. Men and Y. Zhang, Synth. React. Inorg. M. 2015, 45, 821-827

9. E.N. Jacobsen, W. Zhang, A.R Muci, J.R. Ecker, L. Deng, J. Am. Chem. Soc. 1991, 18, 7063-7064

10. I. Kuźniarska-Biernacka, A.R. Silva, R. Ferreira, A.P. Carvalho, J. Pires, M. Brotas de Carvalho, C. Freire and B. De Castro, New J. Chem. 2004, 28, 853-858

11. Q. H. Xia, H. Q. Ge, C. P. Ye, Z. M. Liu, and K. X. Su, Chem. Rev. 2005, 105, 1603-1662

12. W. Zhang, E.N. Jacobsen, J. Org. Chem. 1991, 56, 2296-2298

13. R. Zhao, Y. Tang, S. Wei, X. Xu, X. Shi, G. Zhang, Reac. Kinet. Mech. Cat. 2012, 106, 37-47
14. H. Tanaka, M. Kuroboshi, H. Takeda, H. Kanda, S. Torii, J. Electroanal. Chem. 2001, 507, 75-81

15. J. Reyes, J.A. Cubillos, C. Montes and A.L. Villa, Ing. Investig. 2008, $28,37-44$

16. J.A. Cubillo, S. Vásquez, C. Montes, Appl. Catal. A. 2010, 373, 57-65

17. J.P. Collman, L. Zeng, and J.I. Brauman, Inorg. Chem. 2004, 43, 2672-2679

18. R. Irie, K. Noda, Y. Ito, T. Katsuki, Tetrahedron Lett. 1991, 31, 1055-1058

19. G. Grigoropoulou, J.H. Clark and J.A. Elings, Green Chem. 2003, $5,1-7$

20. P. Pietikäinen, Tetrahedron Lett. 1994, 35, 941-944

21. A. Corma and H. García, Chem. Rev. 2002, 102, 3837-3892

22. B. Meunier, E. Guilmet, M.E. De Carvalho, R. Poilblanc, J. Am. Chem. Soc. 1984, 22, 6668-6676

23. T. Linker, Angew. Chem. Int. Ed. Engl. 1997, 36, 2060-2062

24. B.A. Frontana-Uribe, D. Little, J. Ibanez, A. Palma, R. Vasquez-Medrano. Green Chem.. 2010, 12, 2099-2119

25. A. Palma, J. Cárdenas, B.A. Frontana-Uribe. Green Chem.. 2009, 11, 283-293

26. M. Hall, B. Hauer, R. Stuermer, W. Kroutil, K. Faber, Tetrahedron: asymmetry. 2006, 17, 3058-3062

27. J. Gramshaw, K. Sharpe, J. Sci. Food Agr. 1980, 31, 93-98

28. O.I. Yarovaya, O.V. Salomatina, D.V. Korchagina, M.P. Polovinka, V.A. Barhash. Butlerov communications. 2002, 2, 51-56.

29. N. Tajidin, S. Ahmad, A. Rosenani, H. Azimah, M. Munirah, Afr. J. Biotechnol. 2012, 11, 2685-2693

30. P. Besse, H. Veschambre, Tetrahedron. 1994, 50, 8885-8927.

31. C. Mercier, P. Chabardes, Pure Appl. Chem. 1994, 62, 1509-1518

32. E.R. Vásquez, Rev. Invest. Univ. Quindío. 2010, 20, 24-28.

33. R. Negrelle, E. Gomes, Rev. Bras. Pl. Med. 2007, 9, 80-92.

34. C P. Horwitz, S. E. Creager, R. W. Murray, Inorg. Chem. 1990, 29, 1006-1011

35. APHA, AWWA, WEF. Standard Methods for examination of water and wastewater. 20th ed. Washington: American Public Health Association; 1998, 4-53. 